\title{
PRICE CONTROLS, ANTITRUST LAWS, AND MINIMUM PRICE LAWS-THE RELATION BETWEEN EMERGENCY AND NORMAL ECONOMIC CONTROLS ${ }^{\dagger}$
}

\author{
Robert V. Faragher $\ddagger$ and Fritz F. HeimanN*
}

In $195^{\circ-}$-as in $194^{2-w h e n ~ s h a r p ~ i n f l a t i o n a r y ~ m o v e m e n t s ~ b e g a n ~ t o ~ d i s r u p t ~ t h e ~}$ economy, drastic economic controls were imposed. At the same time the great body of law governing economic activity in times of normalcy remained in effect. We propose to explore the interaction between price controls and two of the most important types of "normal" economic regulation-the federal antitrust laws and state minimum price laws. This subject is practically unexplored.

Perhaps one reason why so little has been written about the interaction between price controls and the antitrust laws is because some experts feel that the two are mutually exclusive. The argument runs as follows: The purpose of the antitrust laws is to insure the proper functioning of the free market system. Price controls, on the other hand, are designed to suspend the operation of the market mechanism. Consequently, whenever price controls are in effect the antitrust laws are deposed. The argument has a ring of logic; however, the facts-as our article will show in detail-do not support it. The antitrust laws and price controls are not mutually exclusive, because price controls never suspend the operation of the market completely. There are always some areas where competitive forces keep selling prices below ceilings. Furthermore, the antitrust laws are not just concerned with prices, but deal with many other aspects of business activity, such as exchanges of information, trade association practices, and other forms of mutual action. In this area, the administration of the price control program-by the use of industry advisory committees and voluntary agreements-presents a number of serious anti-trust problems.

While the view that price controls and the antitrust laws are mutually exclusive may have prevented some light from being shed on their interaction, a second view has produced great heat, if no more light. That view holds that price controls

tThe opinions expressed are the authors' and do not necessarily reflect the official position of any Government agency, past or present, or of the General Electric Company.

$\ddagger$ A.B. 1933, LL.B. I935, University of Illinois; J.S.D. 1937, Yale Law School. Member of the Illinois, New York, and District of Columbia bars. Practicing attorney, Washington, D. C. Lecturer in law, Catholic University of America. Associate Chief Counsel, Office of Price Stabilization, 1951-1953. Author (with Fritz F. Heimann), Price Stabilization During a Period of Cold War, 41 Calı. L. Rev. 93 (r953).

*A.B. 1948, J.D. 1951, University of Chicago. Member of the District of Columbia bar. Attorney, General Electric Company, New York City. Assistant to the Associate Chicf Counsel, Office of Price Stabilization, r95I-r953. Author (with Robert V. Faragher), Price Stabilization During a Period of Cold War, $4 \mathrm{I}$ Calrf. L. Rev. 93 (1953), and The Regulatory Structure for Constumer Durable Goods: Rococo Run Rampant, 38 Iowa L. REv. 263 (1953). 
are in sharp conflict with the antitrust laws. A good many devoted "antitrusters" believe this.

The most elaborate exposition of this position is a 53-page article entitled "Monopoly and Mobilization: The Conflict between Direct Controls and the Antitrust Laws." It is the work of George and Rosemary Hale, who have contributed many articles to antitrust literature. Their account of what happens when price controls are in effect is hair-raising. The most sacred doctrines of antitrust law are violated in broad daylight-and with frequency. The free enterprise system is strangled and the rights and liberties of the American people are despoiled. ${ }^{2}$

Our article offers the reader nothing so sensational, for we have found the relationship between the antitrust laws and price controls to be relatively unspectacular. We shall discuss their relationship, not on the level of abstract legal and economic dogmas-which produces the specters that made the Hales shudderbut rather on the basis of the principal day-to-day problems which arose in the administration of the price control program.

It was on the administrative level that a modus vivendi had to be worked out, for Congress provided very little guidance. The statute included only a limited provision dealing with the use of voluntary agreements, a few rules regarding the use of industry advisory committees, and some Fourth of July oratory urging the price controllers to comport themselves so as to further the American system of competitive enterprise. ${ }^{3}$ Toward the end of the price control program, Congress became exercised about the administrative solution-or lack of solution-of the state minimum price law problem. It then provided its own even more dubious formula.

The article is divided into four sections. The first deals with the industry advisory committee program. The basic problem here was to enable OPS to obtain essential advice and cooperation from the industries it regulated, and yet to avoid any possibility that the committees could be used for collusive action by industry, as the Department of Justice feared.

The second part is concerned with the use by OPS in its regulations of pricing methods and techniques which were considered questionable by the Antitrust Division.

${ }^{2} 47$ N. W. L. REv. 606 (1952).

'The Hales' technique for conjuring up hobgoblins is very simple. At all points they compare the theoretical operation of a perfectly working competitive economy with a price control economy as imagined by Westbrook Pegler and his friends. For example, it is pointed out that in a competitive economy, there is complete freedom of entry-new firms and new products can enter the market at will. However, when controls are in effect, there are so many forms to be filled out, there is such an encumbrance of red tape, that virtually all new development is stifled. The Hales conveniently fail to observe that during a period when 50 billion dollars or more of annual industrial capacity is devoted to defense production the resulting shortages and inflation might conceivably have some little effect on their perfectly functioning competitive economy. It might also be noted that the actual workings of a price control program have little in common with the nightmares of Mr. Pegler and the Hales. For example, contrary to the widely-spread fable, there never was a 27,918 word cabbage regulation. In fact, OPS never controlled the price of cabbage.

${ }^{3}$ Section 401 of the Defense Production Act of I950, 64 STAT. 803 (1950), 50 U. S. C. App. \$2I0I (Supp. 1952). The provisions dealing with voluntary agreements and with industry advisory committees are discussed below. 
The third section deals with the voluntary agreements and programs which were adopted in an attempt to stop inflation before the imposition of the general freeze. Here Congress recognized the possibility of conflict between antitrust and price control considerations, and in part defined the relation between the two. Serious questions remained, however, for administrative solution.

The problems created by state minimum price laws provide the fourth section of the article. These laws, as is also true of the antitrust laws, are not addressed to the economic conditions existing in a period of inflation. In fact, as will be shown, minimum price laws are apt to have a decidedly inflationary effect. Thus, a real conflict exists. OPS's troubles with these state laws provide an interesting case study of what Professor Galbraith has termed the "obscene politics" of price control.

\section{INDUSTRY AdvisoRy COMMiTteEs}

A major area of contact between price controls and the federal antitrust laws was the OPS industry advisory committee program. That program was based on the premise that the success of price controls depends on the advice, understanding, and cooperation of industry. While surveys and available data may provide valuable information on business practices, prices, and costs, they alone are not adequate to assure fair and workable regulations. One of the best ways to obtain needed advice and understanding of industry is to assemble a representative group from industry and discuss the problems of a regulation with them.

There was provision for consultation with industry committees in both the Emergency Price Control Act of 1942, under which OPA operated, and the Defense Production Act of 1950, which gave OPS its authority.

The reason for conflict between an industry advisory committee program and the antitrust laws is readily apparent. A fundamental precept of antitrust philosophy is that joint action by different members of an industry is suspect-and if taken in order to influence prices, illegal. The Antitrust Division of the Department of Justice strongly objects to exchanges of information regarding costs and prices by members of industry because such exchanges frequently provide a basis for concerted action regarding prices.

Industry advisory committees admittedly engage in certain activities normally considered questionable under antitrust concepts. Prices, costs, terms and conditions of sale, and other factors related to market behavior are the subject of discussion among representatives of competing companies. However, there is a marked distinction between normal times and a period of price controls. The fact that controls are in operation indicates that the market mechanism is significantly, if only temporarily, suspended. The job of the antitrust laws-insuring the effective functioning of the market mechanism-obviously is affected by the existence of price controls.

This does not mean that a price control program and, in particular, an industry advisory committee program should ignore antitrust considerations. After all, a 
price control program is a temporary measure, while the objectives of the antitrust laws are of permanent concern. The OPS industry advisory committee program was in fact run with maximum concern for these objectives and was far more consistent with these objectives than that of OPA.

\section{A. The Legislative Framework}

The statutory basis for the OPS industry advisory program was contained in two sections of the Defense Production Act." Section 404 provided that "In carrying out the provisions of this title, the President shall, so far as practicable, advise and consult with, and establish and utilize committees of, representatives of persons substantially affected by regulations or orders issued hereunder." Section 7or (b) (ii) was intended to insure that the membership of advisory committees would be representative. It provided that, ". . . in their formation there shall be fair representation for independent small, for medium, and for large business enterprises, for different geographical areas, for trade association members and nonmembers, and for different segments of the industry. ...."

There were a number of significant differences between the statutory basis of the OPS industry advisory committee program and the industry consultation requirements of the Emergency Price Control Act of 1942. The principal difference was that the Emergency Price Control Act vested in industry a substantial amount of control. The I942 Act directed the Price Administrator to appoint an IAC "at the request of any substantial portion of the industry." It further provided that "the committee shall select a chairman from among its members and shall meet at the call of the chairman," and that the "administrator shall from time to time, at the request of the committee, advise and consult with the committee. ..."

A second difference was that the 1942 Act merely provided that the committees should consist "of such number of representatives of the industry as may be necessary in order to constitute a committee truly representative of the industry." The Defense Production Act, as noted, spelled out a detailed standard for representation.

The differences between the I942 Act and the r950 Act clearly made the latter preferable from an antitrust standpoint. The $195^{\circ}$ Act emphasized the idea that the committees were of a purely advisory nature and were to provide such advice as OPS might request. Under the I942 Act, the considerable amount of initiative which committees had, gave them somewhat the character of independent regulatory bodies for the particular industry. ${ }^{6}$

\footnotetext{
'Sections 404 and 7or(b)(ii), 64 Stat. 807 (1950), 65 Stat. I38I (I950), 50 U. S. C. App. $\$ \$ 2104,2151$ (Supp. I952).

${ }^{5}$ Sec. 2(a), 56 Stat. 24 (I942), as amended, 6o Stat. 670, 50 U. S. C. App. \$902 (1946). The following quotations in the text of provisions of the 1942 Act are also from Sec. 2(a).

'The Attorney General's report of Dec. 7, r950, stated:

"Experience indicated in World War II that business advisory committees ( $I$ ) were often delegated too much policy making power; (2) were frequently composed primarily of the larger and more infuential members of an industry; (3) did not always make technical information exchanged in committee conferences available to all interested members of the particular industry; and (4) engaged in activities outside the scope of their delegated functions."
} 


\section{B. The Procedural Framework}

The difference between committees established by OPA and those established by OPS becomes even clearer when the applicable procedural regulations are compared. OPA spelled out the aforementioned statutory requirements in Procedural Regulation No. 13. Article IV dealing with "Operations of Committees" provided not merely for the election of a chairman and a vice chairman by the committee, but also for a secretary and a treasurer, or a secretary-treasurer. Nonmembers of the committee were eligible for election as secretary or treasurer. The committee also had the right to hire "other assistants." $\mathrm{PR}$ I3 further permitted the committee to receive voluntary contributions from industry representatives for committee maintenance, such as salaries and expenses of the staff and traveling expenses of the committee members. ${ }^{8}$ Trade association secretaries generally served as secretaries to the committees. As for the calling of a meeting, PR $\mathrm{I}_{3}$ provided for dual responsibility. Meetings could be called by the OPA price executive who had jurisdiction over the particular industry or by the industry chairman. ${ }^{9}$ While the industry chairman, in the case of meetings called by him, had the responsibility to see that minutes were kept, meetings could take place without the presence of any government representatives. Furthermore, at meetings called by the industry chairman, the makeup of the agenda was entirely in his discretion. PR I3 also provided for "formal committee action." Formal action was defined as a "representation, recommendation or petition ... coming from the committee ... agreed to by a majority of the members present at a meeting ... at which a quorum was present." Provision also was made for minority reports.

OPS Price Procedural Regulation 2 (I6 FED. REg. I234 (I95I)) differed markedly from OPA PR 13 . Section 2 of PPR 2 made it clear that committees were to function "only in an advisory capacity." Responsibility for the appointment of committees was vested exclusively in the Director of Price Stabilization. ${ }^{11}$ Likewise, the Director had full authority to disband committees. ${ }^{12}$ As for the calling of meetings, this was the sole responsibility of the Director. Section 13 entitled "The Call" did, however, provide that the Director might call a meeting when requested by three committee members "if he deems it desirable." PPR 2 also made it a specific requirement that all meetings "shall be held in Washington, D. C. and shall be under [the Director's] supervision." ${ }^{13}$ There was no comparable provision in PR 13, and OPA committee meetings were frequently held in hotel rooms and at trade association headquarters or at other places chosen by the industry. PPR 2 also required that the "Director of Price Stabilization or his representative shall act as chairman of each Industry Advisory Committee and shall preside over all Committee meetings."14 It also provided that " the agenda for each meeting shall be initiated and formulated by the Director or his representative."15 No provision was made for secretaries of committees, for committee employees, or for committee expenses. Thus, under

${ }^{7}$ Sec. 1300.I010.
${ }^{10} \mathrm{Sec}$. 1300.1013.
${ }^{13} \mathrm{Sec} .14$.

\footnotetext{
${ }^{8}$ Sec. 1300.1011.

${ }^{11}$ Sec. 4.

if Sec. 16 .
}

\footnotetext{
'Sec. 1300.1012.

12 Sec. 11.

${ }^{16}$ Sec. 17.
} 
PPR 2 the committee was simply a group of persons from an industry called in to advise the Director upon his request.

\section{Justice Department Requirements}

The Department of Justice took an active interest in the industry advisory committee program from the beginning of the post-Korea mobilization program. Peyton Ford, the Deputy Attorney General, wrote Alan Valentine, ESA Administrator, on November 7 , I950, laying down the minimum requirements for the operation of the advisory committee program. The letter stated that the Department considered that the decision as to the necessity for the formation of committees and the responsibility for their formation rested with the particular agencies. ${ }^{16}$

The five requirements laid down by Mr. Ford "to minimize the possibility of violation of the antitrust laws" were:

r. There must be statutory authority for the employment of such committees or there must be an administrative finding that it is necessary to utilize such committees to perform certain statutory duties.

2. The agenda for such committees and their meetings must be initiated and formulated by the government.

3. The meetings to be held must be at the call of and under the chairmanship of full-time government officials.

4. Full and complete minutes of each meeting must be kept.

5. The functions of such committees must be purely advisory and any determination of action to be taken must be made solely by government representatives.

Mr. Ford pointed out that as long as IAC activities were carried on within the specified limits, they would not constitute an independent violation of the antitrust laws. He emphasized, however, that it should be made clear to committee members that "the Department of Justice retains complete freedom to institute proceedings, either civil or criminal or both, in the event that any particular plan or course of action is used to accomplish unlawful private ends."

As the preceding discussion of PPR 2 indicates, the legal framework of the OPS industry consultation program carefully complied with the requirements set forth in the Ford letter. It is indicative of an element of perversity that the Antitrust Division never saw fit to give official approval to PPR 2. No logical reason for this was ever given. At no time did the Department suggest any improvements or even object to any specific provisions of PPR 2. In a "tie-in" maneuver which ought to have been particularly abhorrent to good "antitrusters," the Department insisted that OPS turn over the transcript of the newsprint industry advisory committee meeting as a precondition for Justice Department examination of PPR 2. For reasons discussed later, ${ }^{17}$ OPS did not comply. The Department of Justice

${ }^{10}$ The Antitrust Division advised OPS that it did not require the fling of IAC membership lists but relied upon OPS to determine the qualifications of committee members in accordance with Section 70r(b) (ii).

${ }^{17}$ Pp. 660-66I, infra. 
gave its apostolic blessing to the NPA equivalent of PPR 2 which, it is worth noting, did not comply with the Peyton Ford requirements as closely as did PPR 2. No significant lesson for the future can be drawn from this. ${ }^{18}$

\section{The Controversy over Trade Association Participation}

On May 8, I95I, Senator Maybank, Chairman of the Joint Committee on Defense Production, wrote to OPS Director DiSalle raising several questions regarding the OPS industry advisory committee program. Senator Maybank was particularly interested in the question of trade association participation. In his answer of May 28, Mr. DiSalle expressed general satisfaction with the operation of the industry advisory committee program and pointed out that he did not consider any amendment necessary.

On the question of trade association participation, Mr. DiSalle indicated that the OPS standards for IAC membership required employment with a firm. Where a trade association officer met the employment requirement, he was eligible for membership. Conversely, full-time trade association employees were not eligible. Attendance at meetings, Mr. DiSalle pointed out, was confined to committee members and qualified government personnel. Trade association secretaries could not sit in as observers, since OPS did not permit any observers to attend. Mr. DiSalle felt that the presence of observers would destroy the free give-and-take between the men who must live with the regulations and the men who write them. He went on to say that in his opinion small business was more adequately protected by having its fair share of committee members than by having professional advocates. Mr. DiSalle added, however, that OPS engaged in frequent consultation with paid trade association representatives, outside of the IAC program.

Senator Maybank raised the same question regarding trade association participation with the Department of Justice. Peyton Ford replied in a letter dated June 6, pointing out that it was the view of the Department of Justice that "if trade association executives are permitted to take part in industry advisory committee activities either as members or observers they may be in a position to create an atmosphere in which the interests of special groups rather than those of the public would become paramount." He concluded that government mobilization officials could obtain ample industry information by direct consultation with trade associations rather than direct trade association participation in industry advisory committees.

On June 6, I95I, George P. Lamb, Chairman of the American Bar Association Committee on Trade Associations, testified before the Senate Banking and Currency Committee. He advocated an amendment to Section 7or (b) (ii) to provide that industry advisory committees "appoint a secretary and/or counsel who may, if

\footnotetext{
${ }^{18}$ In addition to the Peyton Ford letter, the Department of Justice sent a second letter to the various agencies using industry advisory committees. In this letter, dated March 15, 195I, Assistant Attorney General Morison pointed out alleged improprieties. No abuses were specifically charged to OPS. The principal additions made by this letter to the requirements of the Peyton Ford letter were the insistence that "the requirements as to committees are also applicable to subcommittees, panels and other subgroups." Mr. Morison also stated that committee membership should be limited to business enterprises actually engaged in the industry concerned.
} 
not a member of the committee, attend all meetings of such committee but without vote."18a In a highly emotional statement, Mr. Lamb set out the desirability of the proposed amendment. He told the story of a lawyer who was asked to attend an IAC meeting but was not permitted to do so because of the rule against observers. Mr. Lamb stated that: "[the exclusion of lawyers] makes my blood freeze. One of the early steps in a dictatorship is to deprive citizens of the right to counsel of their own choosing. It should never be permitted in this country."19

On June 22, Peyton Ford wrote to Representative Spence, Chairman of the House Banking and Currency Committee, commenting on the amendment proposed by Mr. Lamb. He said:

The entire notion of appointing a secretary and counsel for advisory committees is directed toward making committees self-contained entities. This is completely at variance with the concept of the committee function of advising government officials when they request advice. To appoint a paid member of a trade association who is not a responsible government official and who is not an active member of the industry concerned to perform these functions for committees would give each such committee a separate status with an accompanying lack of responsibility to the government which is not contemplated to further the purpose which such committees should serve. Further, the idea of a committee counsel who is not a government official is completely violative of the statutory concept of the role of committees.

Congress rejected the amendment and the statutory framework for industry consultation remained unchanged.

\section{E. Celler Committee Investigation}

In the summer of 195x, the Monopoly Subcommittee of the House Judiciary Committee (the Celler Committee) held a series of hearings on the mobilization program. One of the Committee's chief points of interest was the operation of industry advisory committees.

Among the things questioned by the Committee were nonrepresentativeness of particular committees, and trade association participation. It was also concerned that committees might have served as convenient vehicles for discussions by industry members of important competitive factors unrelated to the advisory function of a committee; and that committees were used to gather and compile statistical data. In its particular examination of practices of the OPS IAC's, the Committee referred to the possibility that industry advisory committees may have done more than simply give advice. The Committee was afraid that in certain instances actual policy and regulatory matters were brought up for decision by the industry advisory committee.

An analysis of the specific complaints made against OPS practices raises some doubt as to the validity of the charges. As the Committee's report itself admitted, the use of the term "agreement" in the minutes of an industry advisory committee

\footnotetext{
${ }^{18 a}$ Hearings before the Senate Committee on Banking and Currency on $S$. 1397, 82nd Cong., Ist Sess., 2343 (195I).

20 Id. at 2342 .
} 
may mean simply that the committee agreed on what their recommendations should be or concurred with what the government proposed. The Committee's conclusions run at times into certain semantic difficulties which ignore the real facts of industry advisory committee procedure. ${ }^{20}$

\section{F. The Effect of Antitrust Consent Decrees upon the Formation of Industry Advisory Committees}

Special problems were posed in industries subject to Sherman Act or Clayton Act consent decrees containing broad prohibitions against industry discussions and exchanges of information. Under OPA, the practice developed of obtaining an amendment of the consent decree to permit the appointment of an industry advisory committee. While this settled the legal problem, it was impracticable because of the time and trouble involved. In many cases, delays in selecting committees and holding meetings could have had serious effects on regulatory programs.

OPS was able to work out a more flexible solution. In a number of instances, the Department of Justice permitted OPS to hold industry advisory committee meetings with industries under consent decrees, requiring merely that the usual standards should be observed. Representatives of the Justice Department gave oral assurances to the Chief Counsel of OPS that the activities of these industry advisory committees would not be considered violations of the antitrust laws and that no contempt proceedings would be instituted against defendants whose officers or employees were members of those industry advisory committees. ${ }^{21}$ Meetings were held on the basis of these assurances in the corn-milling industry; the bolt, nut and rivet industry; and the screw-manufacturing industry.

In other instances, OPS decided against setting up industry advisory committees because of antitrust problems. This was the case in the flatglass industry. The prohibitions of the consent decree there were so sweeping that in the opinion of the Department of Justice almost any discussion at an industry advisory committee meeting would be a violation of the decree. As there were only five manufacturers in the industry, OPS decided not to press the issue, and consulted individually with the five firms.

A meeting of the refractories industry advisory committee was held, although that industry was subject to a Federal Trade Commission consent order. Chairman Mead had previously written to OPS on June 4, 195x, that he had no objection to the proposed meeting provided the requirements of the consent order were observed. He pointed out that certain difficulties might arise regarding the exchange of current and future price information by members of the industry, this being specifically banned under the consent order. He suggested, however, that OPS could easily

\footnotetext{
${ }^{20}$ This search for significant meanings where none are to be found recalls the reply made by Sigmund Freud to overzealous disciples who felt that there must be a significant meaning behind his cigar smoking. "Sometimes a cigar is just a cigar," the Father of Psychoanalysis reminded them.

${ }^{2 x}$ As a technical matter, the question can be raised whether the Antitrust Division can grant absolution from a court order. Theoretically it is only the court which can modify its own order. The procedure which was developed, however, looked at the realities of the situation, i.e., it is the Antitrust Division which does the policing.
} 
enough obtain the prohibited information in writing from the individual members rather than at an open meeting.

G. The Requirements for Consultation and Representativeness

The operation of the OPS IAC program raised a number of closely related legal issues concerning the requirement for industry consultation and representativeness of committees. These were the principal questions:

(I) What is the extent of the OPS obligation to consult with industry?

(2) Must all consultation be through formal industry advisory committees?

(3) What are the requirements relating to the composition of committees?

It is clear that the OPS obligation to consult with industry was not an absolute one. Section 404 of the Act provided that "so far as practicable" OPS shall "advise and consult with and establish and utilize committees" of representatives of persons "substantially affected by its orders." OPS interpreted this language to mean that there were two separate obligations-first, a general obligation to advise and consult, and second, a more specific obligation to establish and utilize committees. The limitation upon the OPS obligation was provided by the phrase "so far as practicable."22 This clearly applied to both obligations.

Also of some importance in spelling out the scope of the OPS obligations was Section 709 (50 U. S. C. App. \$2159 (Supp. I952)). It provided that all regulations should be accompanied by a statement indicating that "there has been consultation with industry representatives, including trade association representatives ... or that special circumstances have rendered such consultation impracticable or contrary to the interests of the national defense." The Section concluded, however, with the important proviso that no regulation "shall be invalid by reason of any subsequent finding by judicial or other authority that such a statement [regarding consultation] is inaccurate."

OPS at all times took the position that it was within its administrative discretion to decide whether there were "special circumstances" which made consultation "impracticable" or "contrary to the interests of national defense." Its position was upheld by the Emergency Court of Appeals in Norman-Frank, Inc. v. Arnall, ${ }^{23}$ a protest against the retail automobile regulation, SR 5 to the GCPR (I6 FED. REg. I769 (195I)). One of the grounds of the protest was that the Director in issuing the regulation did not conform to the statutory requirements with respect to prior consultation with representatives of the industry affected. The Statement of Considerations accompanying that regulation stated that "No formal consultations with representatives of the industry have been possible because of the urgency of the situation."

The court, in an opinion by Judge Magruder, discussed the consultation require-

${ }^{22}$ A similar qualification is contained in Section $70 \mathrm{r}(\mathrm{b})$ (ii) which established detailed standards for representativeness, designed to assure small business participation. It provided for the appointment of such committees "as shall be appropriate." This qualification, it is reasonable to assume, is synonymous with the "so far as practicable" limitation of Section 404.

${ }^{23} 196$ F. $2 d 502$ (E. C. A. I952). 
ments at some length. He placed special emphasis on the final clause of Section 709 which provided that no regulation should be invalid by reason of any subsequent finding by judicial or other authority that the consultation statement was inaccurate. Judge Magruder concluded (pp. 504-505): "Since it is stated by the Direstor that because of the urgency of the situation no formal consultation with representatives of the industry was possible, we have no jurisdiction to review the factual accuracy of this recital."

Even though the administrative finding regarding the propriety of consultation was not judicially reviewable, this, of course, did not mean that the requirements as to consultation or representativeness of the committees could be ignored or flouted. Section 709 simply indicated that Congress realized that judicial examination into this issue would be exceedingly difficult and unsatisfactory. Congress itself had potent means to insure administrative compliance with its requirement. For example, the Celler Committee, as has already been indicated, devoted considerable time to the conduct of industry advisory committees. Both the Senate and House Banking and Currency Committees at various hearings checked upon OPS compliance with the consultation requirement. In addition, as has been noted already, ${ }^{24}$ the Justice Department displayed an active interest in the conduct of the IAC program. The proper observance of the representativeness requirements of Section 7or(b) (ii) was one of its particular concerns.

The adequacy of industry consultation was also raised in the Sunshine Biscuits case, ${ }^{25}$ a protest against CPR 36 , the used steel drum regulation (I6 FED. REG. 445I (195I)). The used drum business-which is of considerable importance during a period of steel shortage-involves three groups. First, there are the so-called "emptiers." These include all the many different businesses which obtain products in drums, and have empty drums to dispose. Second, there are the used drum dealersscrap dealers who buy used drums from the emptiers. Third, there are drum reconditioners. Sunshine Biscuits, Inc., an emptier, alleged that in the issuance of CPR 36 the consultation requirements of Section 404 were not complied with since no emptiers were represented on the Used Steel Drum Industry Advisory Committee. $^{26}$ The Director's Opinion Accompanying Order Denying Protest admitted that no emptiers were represented on the Used Steel Drum Industry Advisory Committee but pointed out that "there was consultation with emptiers and, in fact, with the corporate sales agent of Protestants which represents many emptiers." Regarding the absence of emptiers on the IAC, the Opinion took the following position:

In view of the fact that emptiers as such are an extremely heterogeneous group and that their income from used drums is an insignificant part of their over-all income, the $\mathrm{Di}$ rector found it impracticable to select individuals, who would be fairly representative of

${ }^{24}$ Pp. 653-654, stipra.

${ }^{25}$ In the Matter of Sunshine Biscuits, Inc., et al., OPS Docket No. I036-I-P, denied Jan, I3, 1953.

${ }^{20}$ The Statement of Considerations accompanying CPR 36 stated: "In formulating this ceiling price regulation the Director consulted with the Used Steel Drum Industry Advisory Committee, industry representatives, and trade association representatives to the extent practicable under existing circumstanccs, and has given full consideration to their recommendations." 
the group as a whole, for membership in the industry advisory committee. The Director's action pursuant to this judgment was not, in his opinion, in conflict with the provisions of Section 404 of the Act. ${ }^{27}$

The conclusion to be drawn from this case is that the "practicability" test applies not merely to the question of whether there must be consultation-the issue in the Norman-Frank case-but also with equal force to the issue of what kind of consultation there must be. Thus, in the absence of "special circumstances," industry must be consulted. However, the question still remains whether, and to what extent, the formal industry advisory committee mechanism must be used. This, too, raises a question of practicability. It is likely that in the vast majority of cases the committee mechanism is practicable.

One of the criteria affecting the practicability of the committee mechanism is, of course, the character and structure of the industry. In an industry where it is impossible to set up a representative committee of approximately 12 or 15 members, it is impracticable to use the committee mechanism. In the formation of committees, various administrative questions are bound to arise which the Director must have discretion to solve. This is aptly illustrated by the used drum case. The used drum dealers and the reconditioners are fairly homogeneous groups whose membership can readily be represented through the committee mechanism. The emptiers on the other hand are a heterogeneous group and furthermore their economic concern with used drums is quite minute. Thus, the procedure used-setting up a formal used drum committee representing dealers and reconditioners, while merely consulting informally with emptiers-was clearly the most practicable way to consult the industry.

\section{H. Minutes and Transcripts of Meetings}

Troublesome questions arose as to who should have access to minutes and transcripts of industry advisory committee meetings. Should they, for example, be made available to industry generally, to the press, or to the Department of Justice? Both policy and legal questions were involved.

Under OPS practice, there was a clear distinction between transcripts, minutes, and press releases. Transcripts were the complete verbatim statements of each speaker. Minutes were the organized accounts of all matters discussed at the meetings, without, however, attribution of statements to particular members. Press releases were summaries of the major items discussed at the meetings, again without any indication of spokesmen.

The requirement in the Peyton Ford letter of November 7, I950 that "full and complete minutes of each meeting must be kept" was incorporated in Price Procedural Regulation 2. ${ }^{28}$ Committee minutes served two purposes: (I) to provide OPS with a full record of committee advice and recommendations for use in formu-

\footnotetext{
${ }^{27}$ Protestant filed an appeal with the Emergency Court of Appeals; however, the case became moot when price controls terminated.

${ }^{2}$ Sec. 18 , Record of Meetings.
} 
lating regulatory action, and (2) to provide a record permitting the Department of Justice to check on whether the minimum requirements for the conduct of industry advisory committees were being met. ${ }^{29}$

As for distribution of minutes, PPR 2 said only that they "shall be mailed to Industry Advisory Committee Members as expeditiously as possible unless the Director of Price Stabilization or his representative determines otherwise, after consultation with the Committee." In addition, the regulation stated that "for public information purposes, a summary of the meeting shall be made available to the press."

The general practice of OPS was to make minutes available only to committee members and the OPS branches and divisions concerned. In a few instances, the Department of Justice asked for and was given copies of minutes of specific meetings. In addition, upon request, copies of minutes were furnished to the Celler Committee over a period of several months. OPS turned down requests for minutes by the press, by industry, and by protestants of price regulations.

Verbatim transcripts were taken in only about 50 of the more than 1,000 industry advisory committee meetings held by OPS-mainly in the early days before a sufficient number of trained conference writers was available. OPS policy was to write minutes, rather than to take verbatim transcripts, whenever possible. ${ }^{30}$ Expense alone was a controlling consideration. ${ }^{31}$

The only formal request for a verbatim transcript came from the Department of Justice, ${ }^{32}$ which asked for a copy of the transcript of the newsprint industry advisory' committee meeting held on June 12, r951. OPS refused because at the start

${ }^{29}$ Letter of Aug. 23, x95I, from Assistant Attorney General Morison to the Director of Price Stabilization.

${ }^{30}$ OPS ManUal Pt. 3, c. II, $\$ 3.4$ (Rev. I) provided:

"B. In rare instances stenographic transcripts will be taken. In the event of such stenographic transcripts, the committee and all those present at the meeting shall be notified at the opening of the meeting that such a record is being made, and the restrictions involved. One original and one copy of such stenographic record will be made and will be deposited in the restricted files of the 'Office of Industry Advisory Committees' for use only by the staff of the OPS and by the committee."

${ }^{31}$ Other reasons for not taking transcripts are well stated in OPA Price Operating InstructionGeneral No. I4, Nov. I, 1944, on Formal Reports of Industry Aduisory Committee Meetings:

"Section 3. Circumstances Under Which Verbatim Transcripts or Stummary Statcments May Be Made. The normal procedure for keeping a formal record of an Industry Advisory Committec meeting shall be that of taking minutes only. . . . A verbatim transcript should be made only when in the judgment of the price executive exceptional circumstances warrant special treatment and then only when the members of the committee fully understand and accept the limitations upon the use of the transcript set forth in the next section.

The practice of taking verbatim transeripts often has at least two undesirable consequences. It encourages the making of speeches for the record. More serious, it often prevents the development of a full and frank discussion of important issues. These ill effects normally outwcigh any advantages gained from the use of verbatim transcripts to support future action and to defend against protests. Moreover, it is a source of friction because of the necessity for refusing to honor requests from Government officials and members of the industry cither for copies of verbatim transcripts or for making public the contents thereof."

32 There were several informal requests for transcripts of meetings, at which, however, no transcripts had been taken. 
of that meeting an OPS representative, in announcing that a transcript was being made, stated that it was for the confidential use of OPS.

Moreover, the OPS view was that, as a matter of general policy, transcripts should not be made available to the Department of Justice, even in the absence of a statement as to confidentiality, because to do so would impair the effectiveness of the committee mechanism. If committee members knew the Department was going to review each of their utterances, they would tend to speak for the record and with caution and restraint. ${ }^{33}$ During World War II, OPA policy also had been not to make transcripts available to the Department of Justice, committees of Congress, trade associations or litigants. ${ }^{34}$

While it may be true, as contended by the Department of Justice, that a transcript is the most complete record of a meeting, one may wonder about the Department's interest in the newsprint transcript. Did it want simply to know whether the meeting was conducted in accordance with the minimum standards of the Peyton Ford letter? More likely it was interested in a little "fishing" and the opportunity to have a look at something not otherwise available.

This presents an important issue for any future price control program in the event consideration should be given to making transcripts available to the Department of Justice. Perhaps it also furnishes an added reason for not making them available. It might turn out that statements in a transcript would be used by the Antitrust Division as supporting evidence for criminal or civil antitrust proceedings or to give leads for further investigation. It is highly unlikely that the transcript would contain more than circumstantial evidence or provide other than a connecting link in a chain of evidence. The more tenuous the link, the greater would be the cry of harassment by the industry affected and the more damaging the blow to the industry advisory committee program.

If it should be decided under any future price control program to allow the Antitrust Division to see transcripts, safeguards should be laid down regarding their use in antitrust proceedings.

There is also an interesting question as to possible antitrust liability in the event it were established that committee members had acted in concert and for a "wrong" purpose in making recommendations for regulatory action. After all, they have only an advisory role. To what extent then would there be insulation from liability even if the government regulations adopted their recommendations? It is the government alone which has the regulatory authority. The committee members simply advise.

In summary then, OPS policy was to make minutes available outside of the agency only to committee members, the Department of Justice, and Congressional Committees, but to withhold transcripts completely.

${ }^{36}$ An excellent statement of this position is contained in a letter from Henry H. Fowler, Administrator of NPA, to Assistant Attorney General Morison, dated May 20, 1952. Mr. Fowler refused to make the transcript of the color TV meeting available to the Department of Justice, even though there had not been any statement as to confidentiality at the start of the meeting.

34 Memorandum of Ethel B. Gilbert to Mr. DiSalle, dated Aug. 15, 1951. 
The statutory basis for the OPS position was Sections 704 and 705 (e) of the Defense Production Act (50 U. S. C. App. \$\$2154, 2155 (Supp. 1952).

Section 704 authorized the making of "such rules, regulations, and orders" as were deemed "necessary or appropriate to carry out the provisions of this Act," containing such "classifications and differentiations ... and reasonable exceptions" as were "necessary or proper to effectuate the purposes of this Act."

Section 705(a) gave OPS authority to obtain "by regulation, subpoena, or otherwise" such information "as may be necessary or appropriate, in [its] discretion, to the enforcement or administration of this Act and the regulations or orders issued thereunder." Section 705 (e) provided that "information obtained under this section" [Section 705] and deemed confidential by OPS, or supplied with a request for confidential treatment, should not be "published or disclosed" unless there was a determination by OPS that "the withholding thereof is contrary to the interest of the national defense." OPS interpreted the language "published or disclosed" to apply to any disclosure outside of the agency including other government agencies. OPS also construed the coverage of Section 705 (a) as broad enough to include transcripts and minutes of industry advisory committee meetings. ${ }^{35}$

As for the distinction between minutes and transcripts, OPS felt that when statements were attributed to particular individuals they assumed a confidential character. Under Section 705(e), OPS therefore "deemed" that transcripts were confidential. Since minutes which, as noted, did not contain any attribution of statements, were not made available to the press, to industry, and to litigants, OPS was not wholly consistent in its application of Section 705 (e). However, it did have Section 704 to fall back on.

As a matter of history, it is interesting to note that the efforts of OPS to preserve the confidential character of transcripts (as well as all other material which had been submitted under a request for confidential treatment or which OPS itself had deemed confidential) were given a quiet burial by Congress on June 30, 1953. After price controls had ended, Congress provided in an amendment to Section 705 (e) (in part) : $:^{36}$

All information obtained by the Office of Price Stabilization under this section 705, as amended, and not made public prior to April 30, r953, shall be deemed confidential and shall not be published or disclosed, either to the public or to another Federal agency

\footnotetext{
${ }^{35}$ In East Ohio Gas Company v. Freehill (U. S. Emergency Court of Appeals No. 619, March 2, I953), the court denied, without opinion, the protestants' motion for production of the minutes of the Iron and Steel Scrap Industry Advisory Committee Meeting. In opposing this motion, the government rclicd on both Sections 704 and $705(\mathrm{e})$.

${ }^{36} 67$ STAT. I3I (1953), 50 U.S. C. A. App. \$2155(c) (1953). Apparently, the purpose of the amendment was to keep any information obtained by OPS under Section 705 from being made public-except to Congress and its committees and the Department of Justice. Congress may well not have been aware that the effect of the language of the amendment was to make available to the Department of Justice for use in antitrust proceedings information and data submitted by companies under a specific request for confidential treatment as well as information and data which OPS itself had dcemed confidential. See H: R. REP. No. 694 (Conference Report to accompany S. 1081, June 30, 1953), 83d Cong., Ist Sess. (I953), and statement of Congressman Wolcott on the amendment, 99 CoNG. REC. 6238-6242 (June 9, 1953).
} 
except the Congress or any duly authorized committee thereof, and except the Department of Justice for such use as it may deem necessary in the performance of its functions, unless the President determines that the withholding thereof is contrary to the interests of the national defense. ...

II

\section{Controversial Pricing Systems}

Probably the single most frequent source of disagreement between OPS and the Department of Justice was over pricing systems employed in price regulations, which the Department considered had unfavorable antitrust consequences. When the GCPR (I6 FED. REG. 808 (I95I)) was issued, the existing pricing structure of the economy was, of course, frozen. In the process which followed of issuing regulations for individual industries, the OPS practice was to adopt the pricing systems which were in current use. This was explained in Mr. DiSalle's letter of August II, r95 to the Celler Committee:

The policy of OPS in formulating regulations covering an industry is to employ so far as practicable the pricing system used by the particular industry. This is necessary in order to avoid disruption of the industry and to stem the inflationary pressures as quickly as possible. It is not the function of OPS to bring about changes in the going practices of American business, nor is it possible to initiate a new pricing system for every industry.

This policy meant that in some instances OPS ceiling prices were expressed in terms of basing points, zones, and uniform delivered prices. At the same time, OPS was well aware of the possible illegality of these systems under certain circumstances. $^{37}$

OPS did not adopt this policy, however, because of any belief that it was precluded by law from changing existing pricing systems. As a matter of fact, it construed the prohibition in Section 402(g) of the Act (50 U. S. C. App. \$2102(g) (Supp. I952)) against compelling "changes in the business practices, cost practices or methods, or means or aids to distribution, established in any industry" as not applying to pricing practices. ${ }^{38}$ Nonetheless, it considered that pricing practices should not be changed unless necessary to achieve significant stabilization objectives.

It was clear that pricing practices involved in determining prices would in many cases be upset in establishing ceiling prices-as, for example, an industry's practice of increasing prices to reflect specific cost increases. However, the same stabilization

${ }^{37} \mathrm{Mr}$. DiSalle, in his letter of Aug. II, I95I to Chairman Celler, stated:

"The Chief Counsel of OPS advises me that there has been no ruling declaring that multiple basing point price systems are illegal per se. The Cement Institute case (FTC v. Cement Institute, 333 U. S. 683) is predicated on a finding of collusion and concerted action to maintain a basingpoint delivered price system for the purpose of suppressing competition. It is possible that a multiple basing point price system might, in and of itself, constitute evidence of discriminatory pricing, subject, however, to the ability of a company or companies involved to rebut this evidence by showing that the price discriminations were the result of good faith efforts to meet competition. Cf. Corn Products Co. v. FTC, 324 U. S. 726; FTC v. Staley Co., 324 U. S. 746."

${ }^{38}$ Memorandum, Section $402(\mathrm{~g})$ of the Defense Production Act of 1950, as Amended, Does not Apply to Pricing Practices, in Hearings before the Senate Committee on Banking and Currency on $S$. 2594 and S. 2645, Pt. 2, 82nd Cong., 2nd Sess. 1301 (1952). 
considerations were not involved in an industry's method or system of expressing prices. A distinction, thus, was made between pricing practices related to determining prices and those related to the manner of expressing prices.

The Celler Committee dealt specifically with this matter in its report, stating in a recommendation to the Director of Price Stabilization: $:^{30}$

The Subcommittee is concerned about the issuance of price regulations framed in terms of basing-point systems, zone-price systems, and other uniform delivered price systems. It therefore recommends that before any regulation which would employ a basing-point system, a zone system, a uniform-delivered-price system, or a form of price leadership is issued, you offcially consult with the Attorney General to obtain his opinion as to the effect of the issuance of such a regulation on the competitive economy. It is also recommended that you maintain general liaison with the Attorney General in the promulgation of other pricing orders which may adversely affect the competitive structure of industry.

In a memorandum to the Director of Price Stabilization dated January I2, 1952, the Chief Counsel of OPS, commenting upon this recommendation of the Celler Committee, stated $:^{40}$

As to the recommendation that we "officially consult with the Attorney General" before specified types of regulations are issued, it is my view that we should not depart from the policy which we have already defined, i.e., avoiding the disruption of existing marketing and pricing methods to the fullest extent possible.

It is my view that the present procedure has the advantage of affording us an opportunity to obtain the views of the Department of Justice without at the same time having the Department placed in the position of reviewing proposed regulations on an individual basis. The technique of carrying this out must rest with OPS because of its responsibility under the Act.

Subsequently, on December 15, I952, Chairman Celler wrote the Director of Price Stabilization asking what action had been taken upon the Committee's recommendation. The Director, in his reply of January 19, 1953, referred to his earlier letter of August II, I95I, to the Committee, ${ }^{41}$ and said that OPS had been following the policy there expressed. He further stated:

As for general liaison with the Department of Justice, this has been constantly maintained, an Associate Chief Counsel having been designated to perform that function. In turn, a representative of the Antitrust Division has carried out a like function for the Department of Justice. Consultation with the Department has been frequent and in several important instances action requested or suggested by the Department of Justice has been taken as indicated below. In essence this consultation has been on a selective basis and has been had whenever it appeared that significant antitrust questions have been involved. I recognize that the policy we have adopted with respect to consultation does not go to the full extent recommended by the Subcommittee.

so The Mobilization Program, Report of the Subcommittee on the Study of Monopoly Power of the House Commatee on the Judiciary, H. R. Rep. No. 1217, 82nd Cong., ist Sess. IOI (I95X) [hereinafter referred to as Celier Committee Report].

${ }^{40}$ Memorandum of Harold Leventhal to Michael V. DiSalle, dated Jan. 12, 1952.

41 P. 663 , supra. 
The recommendation of the Celler Committee for advance consultation with the Department of Justice before the issuance of any regulation involving any of the "questionable" pricing systems, simply would not have been workable. Indeed, the Department itself never advocated that course to OPS. Considerable delay in the issuance of urgently needed regulations, many of which were long overdue, would undoubtedly have resulted.

Furthermore, a policy of changing an industry's pricing system to comply with the Department's preferences would have raised some very fundamental questions. Mere suspicion of collusive action or speculation that perhaps the antitrust laws were being or would be violated certainly would not have justified OPS' changing an existing pricing system. This was so despite the policy expressed in the Defense Production Act that the powers conferred should be carried out in a manner designed to maintain and further the American system of competitive enterprise. Even if the Department had some evidence of illegal use of an existing system in a particular case, a delicate question would have been presented as to the extent to which administrative judgment should be substituted for judicial decision. The price control powers were not intended to provide an opportunity for the elimination of pricing practices deemed harmful by the Department of Justice.

There were a number of instances in which, as a result of consultation, OPS regulatory action took into account viewpoints of the Department of Justice. The following are examples.

I. Before the OPS issuance of CPR I62 (I7 FED. REG. 7I44 (I952)), establishing ceiling prices for beet pulp products, the Department advised that the proposed use of a basing point system might be prejudicial to its proceeding against certain members of the industry against whom a complaint had been filed alleging the illegality of that system. Several conferences were held between representatives of OPS and the Department but there did not appear to be any feasible alternative. At that time, consent decree negotiations were under way and the Department asked that issuance of the regulation be held up temporarily. OPS agreed, but the negotiations were not concluded within the brief period anticipated. OPS advised that it would be necessary to issue the regulation and the Department informally agreed. Before issuance, however, a copy of the regulation was submitted to the Department and it made several suggestions, including addition of the following language: "Should compliance with the regulation conflict with the provisions of any judgment subsequently entered, prompt steps will be taken to amend the regulation accordingly." OPS incorporated these changes in the Statement of Considerations to the regulation.

2. Supplementary Regulation 22 to the GCPR (I6 FED. REG. $3^{8} 3^{\text {I }}$ (I95I)) authorizing American Can Company and Continental Can Company to raise prices for leasing container-closing machines to compensatory levels was issued by OPS at the specific request of the Department of Justice. Decrees had been entered against these companies in suits brought by the Department of Justice alleging that they had 
leased their machinery at nominal rentals, well below actual cost, for the purpose of inducing lessees to purchase their cans rather than those of competitors. Since the purpose of the judgments, which required the companies to raise their prices to compensatory levels, was to restore competition within the industry, OPS considered that the resulting increase in ceiling prices was consistent with the Defense Production Act.

A special regulation had to be issued to permit the companies to comply with the court decrees. This obviously was a cumbersome technique. For that reason, OPS subsequently developed a general adjustment procedure to take care of similar cases. Under this procedure which is discussed below, ${ }^{42}$ adjustments could be made by means of letter orders.

3. As initially drafted, CPR I7 (I6 FED. REG. 3033 (I95x)), establishing ceiling prices for most petroleum products, contained a provision which would have allowed wagon sellers to price on the basis of a designated wagon seller near a marketing territory. This technique had been used by OPA and had advantages of administrative simplicity. The Antitrust Division advised that this pricing system was being challenged in several pending antitrust suits and requested that it not be included in the proposed regulation. In accordance with this request, the provision was omitted.

There were also situations in which the Department of Justice questioned OPS regulatory action, but feasible alternatives could not be worked out by either agency. The following are examples:

I. In 195I, before the issuance of CPR rro (I6 FED. REG. I2872 (I95I)) establishing ceiling prices for copper wire mill products, OPS informed the Department that because of uneven price increases in the industry following the Korean outbreak the ceilings produced by the general freeze (GCPR) were completely distorted and therefore the only practical regulatory action was to establish uniform ceiling prices. OPS advised the Department that since the number of separate items produced by the industry exceeded one million, the only feasible technique for expressing ceiling prices was to utilize portions of the pricing books of several of the principal producers. While it would have been possible to spell out ceiling prices in appendices to the regulation, the necessary cost and time were prohibitive.

The Department objected to the method proposed by OPS on the grounds that the industry might cite the regulation as government blessing for "price leadership." However, it was unable to suggest any feasible alternative. The Department persisted in its objections after the regulation was issued and OPS suggested the possibility of either amending the Statement of Considerations to explain fully the reasons for using the particular technique or sending a letter to the Antitrust Division, which could in turn be sent to the industry. OPS felt either of these steps would largely offset the possible adverse effects which the Department feared might result when the price control program was ended. The Department never responded directly to these suggestions, but continued to express dissatisfaction with the regulation.

${ }^{2}$ P. 670 , infra. 
2. In April 1952, the Department requested OPS to consider revision of Supplementary Regulation 4 to CPR 7 (I7 FED. REg. 2485 (I952)), which authorized the establishment of uniform ceiling prices for sales at both retail and wholesale of certain branded articles. Under this regulation, uniform wholesale and retail ceilings were established upon application by the manufacturer of the particular article. By means of this regulation OPS, in effect, gave recognition to "fair-trading." OPS had issued this regulation because it felt that specific-and uniform-dollars-andcents ceiling prices, were far more effective from a price control standpoint than ceilings which depended upon individual-formula computations by hundreds or even thousands of different resellers. With pre-ticketing-having the manufacturer "ticket" the article with its retail ceiling price-both consumers and enforcement officials could tell at a glance whether there was compliance with ceiling prices.

The Department argued that the regulation was inconsistent with the objectives of the antitrust laws as it appeared to place the government in a position of encouraging both vertical and horizontal price fixing in consumer goods industries. In his reply of April 28, 1952, the Director of Price Stabilization answered Assistant Attorney General Morison's objections in detail. With respect to the regulatory technique, the Director stated:

I believe the matter under discussion encompasses questions which are far broader than those arising under Supplementary Regulation 4. It has been the practice of OPS as it was the practice of OPA to fix dollar-and-cent ceiling prices for vast ranges of commodities and to fix the ceiling prices for commodities in terms of flat markups over cost. In employing these methods of pricing, the Agency based its dollar-and-cent ceiling prices and the prices derived through the application of flat markups upon prices as they existed in some base period, with variations which took account of increasing or decreasing costs.

As for the antitrust aspects, which seriously disturbed the Department, the following excerpt from the Director's letter is of particular significance:

One very important feature of the regulations should not be overlooked: manufacturer and wholesaler applicants do not themselves determine reseller prices. In the first place the prices established under the regulation are ceiling prices and, as stated above, each seller is free, so far as OPS is concerned, to sell at any price he wishes below the ceiling price. Secondly, manufacturers and wholesalers, when they apply merely suggest ceiling prices to the Agency. These suggested prices often are not the prices which the applicants themselves would have fixed. They are prices which, under the standards prescribed in the regulation, must provide resellers with their base period markups. Thus it is the Agency and not the seller, which in all cases determines the price.

Here also, the way was left open for the Department of Justice to suggest modifications.

3. The Department of Justice also objected to the OPS ceiling price techniques for new and used passenger automobiles. Under SR 5 to the GCPR (I6 FED. REg. I769 (I95I)), dealers determined ceiling prices for new cars by reference to manufacturers' suggested price lists, and for used cars by reference to official used car 
guides. ${ }^{43}$ Both of these techniques were explained in the Statement of Considerations as temporary measures to correct the distorted prices during the GCPR base period.

Following earlier conferences between OPS and Department of Justice representatives, at which OPS said that it proposed to abandon these temporary measures, Assistant Attorney General Morison wrote the Director of Price Stabilization on June 5, 195x:

We consider that all of such practices constitute positive deterrents to competition and that they create opportunities for conspiracies and combinations in restraint of trade. Investigations conducted by us in the past and those which we now have under way have made it plain that such pricing techniques are devices frequently used for the violation of the antitrust laws. We would consider it particularly unfortunate if such pricing techniques are given the blessing of a governmental administrative body.

On November 15, I951, OPS issued CPR 94 (I6 Fed. Reg. II639 (I95I)), eliminating the determination of ceiling prices for used cars by reference to the guidebooks and establishing dollars-and-cents ceiling prices. These ceilings were arrived at by harmonizing prices in the major guidebooks, utilizing other current market information, and applying a depreciation factor. OPS action was dictated not so much by antitrust considerations as by the unworkability of the previous technique. For instance, different guidebooks occasionally showed different prices for the same automobile. Furthermore, guidebook prices for the GCPR base period soon became unrealistic as they did not reflect subsequent depreciation.

On October 15, I95I, OPS issued CPR 83 (I6 FED. REG. 10594 (195I)) which provided for the establishment of dollars-and-cents ceiling prices for retail and wholesale sales of new passenger automobiles. These ceilings were based upon the manufacturers' ceiling prices plus existing dealer markups. Use of the manufacturers' suggested price lists by individual sellers was thus eliminated. Allowable charges were also specified in the regulation.

Powerful opposition developed from the National Automobile Dealers Association which insisted that dealers should be permitted to employ their individual base period pricing practices, particularly for the allowable charges specified in the regulation. The Association said that CPR 83 introduced a uniformity which had not theretofore existed. It also objected to the "roll back" imposed on a small percentage of dealers by the 5 per cent limitation on the "preparation and conditioning" charges.

Finally, on August 18, 1952, the Director of Price Stabilization issued a revision of CPR 83 (I7 Fed. Reg. 7572 (1952)). Under this revision, a dealer was authorized to set his ceiling prices upon the basis of his base period practices, including use of the manufacturer's suggested list price (so long as it did not result in a markup higher than that of the base period), and to make whatever additional charges he made in his base period. Where the manufacturer's suggested list price would pro-

13 The issue as to the use of manufacturers' suggested list prices for new cars was first raised by autn. mobile dealers in Texas who claimed that the Texas antitrust laws forbade their use. 
duce a markup lower than that of the base period, the dealer was permitted to use his own base period markup.

Manufacturers' suggested price lists were also used for establishing resellers' ceiling prices in CPR 67 ( 16 FED. REG. 8352 (I95I)) covering machinery and related manufactured goods. This technique greatly facilitated administration and enforcement of price control in this area. Moreover, the use of manufacturers' price lists had been long established industry practice. In some industries subject to the regulation, the number of different parts and accessories sold by a single reseller might run as high as 300,000 . Use of manufacturers' suggested price lists substantially reduced the burden on resellers in determining their ceiling prices.

As a practical matter, it would have been almost impossible to deny resellers the use of manufacturers' published price lists. Traditionally they operated that way. The sheer numbers of items, particularly in the field of automotive and machine parts, made it practically impossible to expect resellers to make individual calculations of ceiling prices and print their own price lists. Normal business practice was clearly to the contrary.

At the same time, the manufacturers did not have carte blanche in computing their suggested list prices. Under CPR 67 , these list prices had to be determined in accordance with the applicable regulation, ${ }^{44}$ and could not be used by resellers if the manufacturer had changed his discount structure since Korea. ${ }^{45}$

No objection to CPR 67 was ever voiced by the Department of Justice, although it possibly may not have been aware of the regulation.

The Robinson-Patman Act

Virtually all techniques for establishing ceiling prices used by OPS took account of industry pricing practices during a prior base period. Sellers were usually required to maintain the same price relationships between various classes of purchasers, as well as the same terms and conditions of sale, ${ }^{46}$ which they had in effect during the base period. As a general rule, OPS regulations were relatively inflexible when dealing with terms and conditions of sale. Very few regulations made provision for modifications of terms and conditions of sale. On occasions, the requirement to maintain customary price relationships and terms and conditions of sale led to conflicts with the Robinson-Patman Act, for some sellers were frozen with differentials between purchasers which were "discriminatory" under the standards of the Robinson-Patman Act.

Unlawful price discrimination between purchasers could, of course, be eliminated "Sec. $3(a)(3)$ of CPR' 67.

${ }^{45}$ SR 2 to CPR 67, issued June 25, I952, did make provision for use of manufacturers' published price lists in certain instances where they had changed their discounts since Korea. I7 FED. REg. 5722 (I952). However, OPS approval was required. See also, CPR 30, Amendment 44, issued January 12, 1953, which authorized manufacturers, upon approval of OPS, to make limited changes in list prices and discounts. I8 FED. REG. 249 (1953).

"Under the heading of "Terms and Conditions of Sale" were included delivery terms, cash, trade and volume discounts, allowances, premiums and extras, deductions, guarantees, warranties, and servicing terms. 
in one of two ways: by increasing the price to the lower-price customer or by decreasing the price to the higher-price customer. Under price controls, the first alternative was normally not available. The second alternative, on the other hand, might have imposed a substantial hardship on the seller. An equitable solution to this dilemma had to be developed.

OPS issued General Overriding Regulation I8 (16 FED. REg. 8830 (I95I)) to enable sellers to apply to OPS for an adjustment of their ceiling prices in order to comply with the Robinson-Patman Act. A seller was permitted to increase some ceilings provided that at the same time he decreased others. GOR 18 required him to make a showing that the proposed ceiling price differentials on a weighted basis would result in no greater over-all realization than he had had during a representative period prior to the freeze. Applications for adjustment under GOR I8 were permitted in all cases where the FTC or a court had made a finding that an illegal price discrimination existed. In addition, a seller was permitted to file for an adjustment if he had "reasonable grounds," supported by an opinion of counsel, to believe that the maintenance of his existing price differentials would be discriminatory.

GOR I8 had proved useful for permitting individual adjustments to deal with Robinson-Patman Act violations. On May 7, 1952, Revision I (I7 Frd. REg. 4236 (1952)) was issued which expanded the scope of GOR I8 to permit sellers to make changes in their prices, required by the Sherman and Clayton Antitrust Acts. In a prior case, a separate regulation had to be issued in order to make an adjustment required by the Sherman Act. This, of course, was an unduly cumbersome procedure.

Unlike the provisions relating to the Robinson-Patman Act, adjustments on antitrust grounds would not be granted where the seller merely had "reasonable grounds" to believe his prices were illegal. Applications could only be filed by sellers who had been found to be violating the Clayton or Sherman Antitrust Acts, and where the judgment or decree of the court required a price increase over OPS ceilings. GOR I8 was also available to sellers operating under a judgment or decree prohibiting them from increasing prices without court approval and where courts had later approved prices higher than OPS ceilings. Unlike the Robinson-Patman Act adjustments, no balancing decreases were required. However, authority was reserved in the Director to require compensatory decreases where he considered this necessary. ${ }^{47}$

"Under GOR 18 , a total of 14 orders was issued. Eleven of thesc dealt with Robinson-Patman Act cases. In ten of the eleven orders, relief was granted. Of the ten, nine of the adjustments were made simply on a showing that applicant had "reasonable grounds" to believe that his price differentials violated the Robinson-Patman Act. In one case, the adjustment was made following a FTC procecding in which the applicant had stipulated that he would change his differentials. Three adjustment orders were issued in Sherman Act cases. All three affected sellers operating under court decrees who wcre not permitted to change prices except on court orders. In the three cases the OPS orders simply confirmed the court orders thereby permitting the seller to use the higher prices the court had previously approved. 


\section{Voluntary Agreements and Programs}

Voluntary agreements and programs entered into by industry at the request of the government were expressly authorized by Sections $402(\mathrm{a})$ and 708 of the Defense Production Act (50 U. S. C. App. \$\$2ro2(a), 2158 (Supp. I952)). Indeed, the OPS position was that the Act required voluntary methods to be tried before mandatory price controls could be imposed. ${ }^{48}$

The Act gave express exemption from the antitrust laws, provided the statutory procedure was followed. ${ }^{49}$

I. Section 708(b) immunized any "act or omission to act ... if requested by the President pursuant to a voluntary agreement or program" approved by him and found by him "to be in the public interest as contributing to the national defense."50 A copy of each "request" and "any modification or withdrawal" was to be furnished to the Attorney General and the Chairman of the FTC, and published in the Federal Register.

2. In addition, Section 708 (c) required any official, to whom the President's power under Section 708 was delegated, to consult with the Attorney General and the Chairman of the FTC not less than Io days before "making any request" and to obtain the approval of the Attorney General to "any request."

Except for a voluntary agreement in the steel industry, discussed later, OPS made no use of the Section 708 procedure. Nevertheless, a number of voluntary stabilization measures were undertaken before formal price controls were instituted. Questions were afterwards raised, and in particular by the Celler Committee, as to why the Section 708 procedure was not followed.

With the onrush of inflation following the Chinese Communists' intervention in Korea in November of I950, and in the absence of any economic preparedness to

${ }^{18}$ Memoranda on The Legislative History with Respect to Requirement that Voluntary Methods Be First Utilized, and Price Stabilization by Voluntary Action before Mandatory Controls Are Imposed, in Hearings before the Senate Committee on Banking and Currency on S. 2594 and 2645, Pt. 2, 82nd Cong., and Sess. 1274 and 1277 (1952).

${ }^{2}$ The views of the Attorney General on this matter were stated in a letter to the Chairman of the Senate Committee on Banking and Currency:

"The desire for legislation of this type results in part from the fact that operations under statutes of the type involved in S. 3936 and the conditions that bring about the enactment of such statutes, occasionally demand some departure from the traditional and independent methods of operation that characterize our business economy in normal times. In addition, it results from the fact that businessmen desire assurance that their cooperation with both Government and other businessmen, which becomes necessary under the circumstances, will not be viewed as antitrust violations. By providing an exemption of this type, the thought is that certain delays and manifestations of noncooperation can be avoided."

Hearings before Senate Committee on Banking and Currency on S. 3936, 81st Cong., 2nd Sess. I96 (1950).

${ }_{60}$ The Celler Committee called attention to the anomaly of having only the act or the omission to act exempted from the antitrust laws and not the agreement. Also the Celler Committee pointed out the confusion in actual administration of Section 708 between the "agreement" and the "request" for certain "acts or omissions to act," and raised the question whether each subsequent act under a single agreement had to be separately requested and in turn approved in advance by the Attorney General. Celler Committee Report, op. cit. stipra note 39 , at 20 and 21 . 
meet the situation, hastily improvised steps were taken to forestall further price increases in several of the basic industries characterized by administered pricing and few producers. Meetings were called by stabilization officials, and company representatives were orally requested to refrain from further price increases without advance notice to ESA. ${ }^{51}$

Understandings on this basis were reached in primary copper, primary lead, primary zinc, sulphur, and ammonia. A similar arrangement was made for antifreeze compounds. These informal, oral understandings were regarded only as "gentlemen's agreements." It is unlikely that any thought was given to their enforceability-the prestige of the few producers being sufficient assurance against breach. Also, in some instances, generous increases had already been taken. No effort was made by ESA or OPS to supplant these loose understandings with more formal agreements before the general freeze was imposed.

There was no clearance with the Attorney General under Section 708 of any of these arrangements-in fact, Section 708 was not regarded as applicable. ${ }^{52} \mathrm{Mr}$. DiSalle took the position in the hearings before the Celler Committee that these were simply "appeals"-not agreements-and therefore were not covered by Section 708.53

The Celler Committee was critical of this distinction, stating: ${ }^{54}$

The subcommittee recognizes the theoretical distinction between an agreement and an appeal, but seriously questions the wisdom of relying on it as a sufficient protection to the members of the industry who participated. ... If there is substantial danger that a court would conclude that the competitors were parties to an agreement, they should be given the protection of a section 708 exemption, even though the arrangement be little more than an appeal and contain no provision for enforcement.

In some industries, for example rayon, producers were reluctant to meet with ESA and consider stabilization measures without some definite assurance of Department of Justice approval. Prompted no doubt by such industry reaction and also by a desire to have formal guidance in this area, Francis Whitehair, General Counsel, ESA, wrote to the Attorney General on January 10, I95I, stating in part:

We believe it would be in the national interest and in accordance with the spirit of the Defense Production Act if we were in a position to assure industry members that their full and frank discussions of prices within the confines of our agenda and meetings, and their commitments to hold prices at our request pending study by this Agency, will not, in and of themselves, render participants liable under the antitrust laws (emphasis added).

In his reply of January I6, I95I, rejecting Mr. Whitehair's views, Assistant Attorney General Morison stated:

\footnotetext{
${ }^{81}$ Most of these meetings were held in the early part of January 1951.

62 Reports of the copper and sulphur meetings contained in memoranda from the Gencral Counsel of ESA to Mr. Alan Valentine, Administrator, indicate that some of the industry representatives inquired as to the effect of the antitrust laws and whether Department of Justice approval was necessary.

" Celler Commitree Report, op. cit. supra note 39, at 13.

${ }^{5} \mathrm{Id}$. at $\mathrm{x} 4$.
} 
As described by you, such agreements appear to constitute voluntary agreements under Section 708 of the Act. Such agreements would, of course, be subject to the requirements of Sections 708(b) and (c) of the Act, including consultation with the Attorney General and the Chairman of the Federal Trade Commission, and approval by the Attorney General.

In retrospect, it is unlikely that the Department of Justice gave any thought to taking action in these cases or even felt that they were of any real consequence from an antitrust standpoint. The problem quickly became moot, however. The GCPR, issued on January 26, I95I, superseded all of these informal arrangements.

Another type of voluntary action had been resorted to earlier. Here also questions as to the applicability of Section 708 were later raised. On December 20, I950, the following telegram was sent by ESA to 250 large manufacturing concerns:

In order to help our efforts to combat inflation, we request that you advise this agency at least seven days before announcing any price increase covering any standard list product or product line on which your annual volume is more than $\$ 500,000$. We are making this request of a selected number of companies in important price areas and count upon your cooperation. Receipt of this information by us does not imply approval or disapproval of such increases.

As might be expected, the responses varied. In some instances, the ESA request was accepted. Regardless of the type of reply, these measures also were not considered by ESA as voluntary agreements subject to Section 708 , but only as holdthe-line appeals. The Department of Justice appeared to agree with this interpretation. In his letter of January I6, I95I to Mr. Whitehair, Assistant Attorney General Morison stated:

The issuance of communications to members of industry requesting certain pricing action on the part of industry members is also considered to be entirely proper so long as such communications do not constitute a request for a voluntary agreement under Section 708 of the Act. Thus, if the Agency initially dispatches such communications without prior consultation with industry and with the view of obtaining an individual commitment from each member, or, if, after a meeting in which preliminary data have been secured and no agreement has been sought or reached, the Agency subsequently determines to send such communications, the action is not deemed to be a voluntary agreement.

However, in his letter of December I8, r95 1 , Mr. Morison raised a further point which might throw some doubt on the January I6 interpretation. He stated:

Further, agreement by individual business enterprises to follow a particular requested course of action constitutes a voluntary agreement requiring approval if in fact the individual is agreeing to follow the requested course of action in consideration of a similar agreement on the part of other business enterprises.

It will be noted that ESA's telegram of December 20 indicated that the same request was being made of a number of other companies. Who is to say that agreement by any one company was not influenced in whole or in part by its understanding that the same agreement was being made by other companies? 
Another example of voluntary action was a wire sent by ESA on December 26, I950, to four petroleum producers in Michigan requesting that they rescind a I2 cent a barrel price increase on crude petroleum. Whether formal approval by the Department of Justice would be required was discussed informally with a representative of the Antitrust Division. It was his opinion that Section 708 did not apply because the telegram called for individual and not group action. While it is true that the tlelegram was addressed individually to the producers, nonetheless all were being asked to comply. In addition, each producer knew the same telegram was being sent to the other producers.

The Celler Committee also felt that there was a valid distinction between agreements made at a meeting and those made as a result of written requests to the individual members of an industry. It stated in its report: ${ }^{.5}$

The Assistant Attorney General thus differentiated between requests for voluntary cooperation made at industry meetings attended by several competitors and individual requests forwarded directly to the several companies whether or not subsequent to a meeting at which preliminary data are secured. The difference between the two situations is that in the latter case there is quite clearly no agreement among the industry members, whereas in the former instance there would be a danger that the voluntary undertakings made by several competitors at a joint meeting would be regarded as an agreement among the industry members, and not just a series of individual agreements between particular companies on the one hand and the Government on the other.

The suggested distinction is at best subtle and highly artificial. It is difficult to tell what motivates persons in agreeing individually to a request to take certain action, whether they are together in the same room or apart in their separate places of business. This is particularly true where it is known in each case that the same request is being made of others.

Measures like the "hold-the-line" telegrams and the informal understandings in nonferrous metals, sulphur, and ammonia are employed only at the outset of a price control program, when staff is small, procedures and policies are being developed, and time pressures are heavy. They are only stopgaps to be replaced promptly by more formal action and are of limited value. Yet at the same time they may have beneficial short-run effects. It is hard to see that they raise any real antitrust issues. After all, they amount only to an undertaking by industry members to give advance notification to the price control agency before making any price increases. They are totally unlike voluntary agreements, such as those relating to production pools and exchanges of technical information. ${ }^{56}$

In any future price control program where similar voluntary undertakings of a purely temporary nature might have to be employed (since we cannot assume that there will be any real preparedness to meet the situation), it would be helpful if the

\footnotetext{
${ }^{55} \mathrm{Id}$. at 15 .

${ }^{50}$ For an excellent summary of the principal voluntary agreements approved by the Attorney Gencral under Sec. 7o8, see Abrams, Antitrust Laws in National Emergency, 36 MrNn. L. Rev. 490, 500-503 (1952).
} 
statutory grant of authority for exemption from the antitrust laws were broader and less rigid. The price control agency should be empowered to get the approval of the Attorney General for specific types of voluntary actions or programs and then simply advise him of the individual actions taken. ${ }^{57}$ If this authority were available, the price control agency should obtain the approval of the Attorney General for each type of voluntary action contemplated including even such actions as the "telegram requests" to refrain from increasing prices without advance notification. By obtaining the Attorney General's approval, antitrust misgivings that might arise in the minds of industry would be avoided and greater cooperation should result.

The purpose of obtaining exemption from the antitrust laws is to permit voluntary action in furtherance of the price control objectives where a violation of the antitrust laws either would or might result. Technically, the exemption is needed only where there would be a violation. It is preferable, however, to obtain the immunity whenever there is any doubt as to legality. Where industry is requested by the price control agency to participate in voluntary undertakings, it is entitled to the full statutory protection.

\section{Steel Voluntary Agreement}

The only formal voluntary agreement in the price control area was on steel mill products. Individual letters were sent by ESA on January I5, 195I, to all members of the industry requesting that no price increases be made without giving ESA 20 days' advance notice. Approximately I40 steel mill producers accounting for about 90 per cent of the industry output agreed to this request. The Section 708 procedure was followed here. Both the Federal Trade Commission and the Attorney General were consulted; the approval of the Attorney General was obtained; and the "agreement" was published in the Federal Register..$^{\mathbf{8}}$

As to the extent of the antitrust immunity granted, the Attorney General's letter of approval stated "it should be clearly understood that any antitrust immunity con-

${ }^{-7}$ The Celler Committce has pointed out the difference in approach under Section 708 and that employed in World War II, referring to a letter written by Attorney General Jackson on April 29, 194I, reading in part:

"Requests for action within a given field, such as the field of allocation of orders, shall be made only after the general character of the action has been cleared with the Department of Justice. If the general plan is approved, thereafter each request for specific action carrying out such plan shall be made in writing and shall be approved by the office of the general counsel of the Office of Production Management or the office of the general counsel of the Office of Price Administration and Civilian Supply, but need not be submitted to the Department of Justice. In the case of any change in the personnel of such offices or if serious practical difficulties arise, this latter arrangement may be revoked upon notice from me.

"Acts done in compliance with the specific requests made by the Office of Production Management or the Office of Price Administration and Civilian Supply and approved by their general counsel in accordance with the procedure described in this letter will not be viewed by the Department of Justice as constituting a violation of the antitrust laws and no prosecutions will be instituted for acts performed in good faith and within the fair intendment of instructions given by the Office of Production Management or the Office of Price Administration and Civilian Supply pursuant to this procedure." Celler Commitree Report, op. cit. supra, note 39, at 20 n. 39 .

${ }^{5 B}$ The text was published in the Federal Register. I6 Fed. Reg. 555 (I95I). Actually, except for the greater formality, the "agreement" here did not differ materially from the December 20, 1950, telegram to the 250 manufacturing concerns and the wire to the Michigan petroleum producers. 
ferred by the Act extends only to those actions taken during its duration and in accordance with the specific request approved by me."

While the agreement was undoubtedly regarded as a temporary measure at the time it was made, even though it had no fixed termination date, it continued in effect throughout the life of price controls. ${ }^{50}$ At various times there were mild pressures to supplant the agreement with a regulation, most of which came from the Department of Justice ${ }^{60}$ and the OPS lawyers. None, however, were of sufficient strength to bring the matter to a head and the wishes of the industry, which insisted vigorously that the agreement was working well and should be maintained, were honored. ${ }^{61}$

Whether the agreement gave any signficant advantages to the industry is doubtful. The industry's real concern may have been fear of the type of regulation that might have been imposed. Outwardly, the industry took great pride that a workable voluntary arrangement-and not a government-inflicted regulation-was controlling prices in its area. ${ }^{62}$ The OPS officials who favored continuing the voluntary agreement were undoubtedly influenced by the good relationships which it created. At the same time, the agreement was basically a loose arrangment and its success depended almost entirely upon the voluntary compliance of the participants.

From a price control standpoint, there were two major defects in the agreement. In the first place, it is doubtful whether the criminal and civil sanctions of the Act would have applied to violations. ${ }^{63}$ Unquestionably, the real deterrent to willful violation was damage to prestige and threat of regulatory action. Injunctive relief would have been academic as the violator under the terms of the agreement could have given 20 days' notice of a price increase. Although a violation would have been a technical breach of contract, it is questionable whether damages could have been recovered, except possibly under a third party beneficiary theory.

A second major defect of the agreement (which proved to be more theoretical than real) was that it placed the initiative for price increases with the steel mills. Upon receipt of notice of a price increase, OPS had only 20 days in which to act. Lacking adequate cost data, OPS would have been in a difficult position in the event of any widespread notices of price increases and probably would have been forced to cancel the agreement and place the industry under the GCPR. The

${ }^{59} \mathrm{Sec}$. I4 (q) of the GCPR kept the agreement alive.

${ }^{60}$ The Department of Justice's position that the agreement should not be continued unless there were compelling reasons was apparently based on the view that it might tend to create the wrong "attitude" in the industry. This philosophy was also expressed in the Report of the Attorney General under Section 708(e) of the Defense Production Act of x950, dated Dec. 7, I950:

"Finally, it is recognized that activities under voluntary agreements and programs are likely to establish codes of conduct inconsistent with free competition which may continue after the expiration of the authority granted in the Act."

Sce also Celier Commmattee Report, op. cit. supra note 39, at 6 , zo.

${ }^{61}$ Minutes of the Second MeEting of the General Steel Products Industry Advisory Committee (Jan. 22, 1952).

"I Ibid.

${ }^{63}$ Memorandum on Steel Voluntary Agreement from Joseph H. Freehill, Chief Counsel, to Mr. Ellis Arnall, Director of Price Stabilization, dated Mar. 17, 1952. 
likelihood of this action was no doubt responsible for the industry's refraining from giving notices of price increases.

A good example of the shortcomings of placing the initiative for price increases with the steel mills was what occurred at the time ceiling prices of zinc were increased. $^{64}$ Notices were sent to OPS by the mills advising that their prices for galvanized steel products would be increased in accordance with their published extras list. A meeting of OPS policy officials was hastily called. There were differences of opinion as to the decision reached and the increase was permitted to go by default. It is clear that if affirmative action by OPS for any increases had been required situations such as this could not have occurred. As it was, if OPS were advised of a contemplated price increase, affirmative action on its part was necessary to prevent the increase. Appropriate action on the part of OPS was hampered by the relatively short notice period.

There were isolated instances of notices of price increases by individual producers which were subsequently withdrawn when OPS expressed opposition. Again, the threat of regulatory action was a powerful deterrent.

In summary, it may be said that the steel voluntary agreement was a reasonably good working vehicle for controlling prices. No serious problems were encountered that would not have been present to a large extent under appropriate regulatory action. Nevertheless, it would have been better as an administrative matter to have placed the industry under formal controls along with other industries. Voluntary agreements were intended only as first steps in the price control program, to be followed by formal regulatory action. It is hard to justify treating a single major industry differently from all others.

\section{IV}

\section{State Minimum Price Laws}

In the conduct of a price control program, conflicts between federal maximum price regulations and state minimum price laws are apt to arise. The lot of a seller who is caught in the middle is in an unhappy one. For if he exceeds the federal ceiling in order to comply with the state law, he is subject to the sanctions of the Defense Production Act. While compliance with the federal ceiling will force him below the state minimum price and bring down the state sanctions.

To generalize, OPS was concerned with two types of state laws. First, there were the general "unfair-competition" statutes. ${ }^{65}$ These were passed by many states during the thirties with the aim of preventing what was called "cut-throat" competition. These laws are usually of a sweeping nature prohibiting the sale of any article "below cost." What a sale below cost may be is frequently defined in only the

\footnotetext{
os Upon instruction of the Director of Defense Mobilization, SR 70 to the GCPR was issued on Oct. 2, 195I, increasing the ceiling prices of domestic slab zinc and primary lead 2 cents per pound. I6 FED. REG. ror23 (r95I).

"Th These "unfair-competition" or "loss-leader" laws should not be confused with the "fair-trade" laws which came into vogue at about the same time. The latter simply provide state authorization for resale price maintenance contracts between manufacturers and distributors.
} 
vaguest terms. ${ }^{66}$ Thus, it is difficult to determine a particular seller's minimum price for a specific article. These laws were aimed at chain stores and other low-markup distributors. After the end of the depression, few of them were actively enforced. Many have become completely dormant, no appropriations having been voted for their enforcement for over a decade. Because of the sweeping coverage of these statutes, their loose draftsmanship, and their sporadic or nonexistent enforcement, a price control agency cannot give them recognition without gutting its own program.

In addition to these highly general laws, OPS was confronted with statutes dealing with the prices of specific commodities. Those relating to milk, liquor, and cigarettes were the most common. These laws are normally somewhat more tightly drafted and more strictly enforced than the "loss-leader" laws. Those dealing with milk and liquor have been on the books for some time. The cigarette laws, on the other hand, are of recent origin-many having been passed in $195 \mathrm{I}$ and $1952 .{ }^{.77}$ Since it is the cigarette laws which posed the biggest problems for OPS, it is worth while to examine them briefly.

The cigarette laws were passed for the benefit of wholesalers and retailers specializing in tobacco products. ${ }^{68}$ Over the past few years, these specialized sellers had steadily been losing ground to their more diversified competitors, particularly chain grocery stores, which were selling for less by taking a smaller markup. To counteract this competition, the cigarette laws provided that a wholesaler must add a certain minimum percentage markup to his cost and that a retailer must add an additional percentage. ${ }^{69}$

The consequences of giving recognition to specific commodity minimum price laws during a period of price controls would clearly not be as serious as in the case of the more general minimum price laws. Enforcement of ceiling prices at the level of fixed state minima would be possible. However, there would be some serious problems. The most fundamental objection is that the principles and standards which a state uses in order to establish minimum prices are different

${ }^{B B}$ The draftsmanship of the unfair competition laws is so poor as to raise a constitutional issuc. A number of state supreme courts have in fact held them unconstitutional because they were too vague to be enforceable.

${ }^{67}$ They have been enacted by a number of states which also have general unfair-competition laws. An important reason for supplanting the general laws with the more specific cigarette laws is the constitutional cloud which hangs over the general laws. See note 66 , supra.

${ }^{68}$ As of March I952, 18 states had legislation directed specifically at the "unfair sales" of cigarettes: Alabama, Arkansas, Colorado, Connecticut, Georgia, Indiana, Iowa, Kansas, Mainc, Massachusetts, New Jersey, New Mexico, Ohio, Oklahoma, Oregon, Pennsylvania, Rhode Island, and Tennessee.

${ }^{0}$ The specified markups for wholesalers vary from 2 to $4-1 / 2$ percent, the markups for retailcrs from 4 to ro percent. The combined markup, for both wholesalers and retailers, varies from 6 to 14 percent, with an average of 9.8 percent. In fact, the real markups are considerably higher than the statutory figures would seem to indicate. This is because of certain peculiarities in the way "cost" is defined: (I) not all discounts are excluded; (2) the value of tax stamps-a very substantial item on cigarettes-is included thus providing a markup on the tax; (3) all fractions must gencrally be rounded upwards. As a result of these peculiarities, for example, the Arkansas law which apparently requires a markup of only slightly more than 8 percent-2 percent for whosesalers plus 6 percent for retailcrsactually results in an over-all markup over invoice cost of 15 percent on carton sales and 21 percent on individual package sales. 
from-in fact, bear no relation to-the standards which a price control agency uses to establish maximum prices. The economic conditions to which minimum price laws are directed are the opposite of those with which price controls are supposed to cope. To use the standards designed to enable small sellers to survive a depression in order to establish ceilings during a period of inflation makes about as much sense as wearing a diving suit to go mountain climbing.

Furthermore, to have effective control of prices of a nationally distributed product like cigarettes, uniform nation-wide administration is essential. Permitting sharp differences in markups between sellers depending solely on which state law is applicable is clearly inequitable. During a period of real shortages, such differences may result in a breakdown of the established distribution pattern-the sellers in high markup states being able to outbid sellers in low markup states for the restricted supply.

The economic effect of state minimum price laws is clearly inflationary. They are designed to prevent price competition. More than that, they are directed against the lowest-priced class of sellers. This is a segment of the economy which from a price control standpoint should be encouraged.

Still an additional difficulty is that of justifying distinctions. If states are granted the right to establish ceiling prices for cigarettes or for liquor, how can the paramount national right over other articles be insisted upon?

Conflicts between state and federal law are not peculiar to a price control program. They are bound to occur under a federal system of concurrent jurisdiction. This was, of course, anticipated from the start, and the Constitution itself provides for the "supremacy" of federal law..$^{70}$

The constitutionally prescribed pre-eminence of federal laws over conflicting state laws has been affirmed in numerous cases since the beginning of our government. Specifically, the supremacy of federal price controls was upheld by the United States Supreme Court in Case v. Bowles, ${ }^{71}$ during the World War II program. The Court said: $:^{22}$

Where, as here, Congress has enacted legislation authorized by its granted powers, and where at the same time, a state has a conflicting law which but for the congressional Act would be valid, the Constitution marks the course for courts to follow.

There are a number of reasons why it was difficult for OPS simply to rely on the legal supremacy of the Defense Production Act over conflicting state laws. First of all, the groups who advocate that state laws should be given recognition have an argument which, superficially, seems very effective. It somehow looks not merely wrong, but highly unfair to establish a price below the state minimum as a ceiling. This is a simple and, therefore, forceful point. To counter it requires the use of

${ }^{70}$ U. S. Const. Art. VI, \$2.

${ }^{72} 327$ U. S. 92 (1946).

72 Id. at ro2. In conformity with this principle, the Supreme Court upheld a lower court decision that an injunction should issue against the Washington State Commissioner of Public Lands to restrain him from disposing of state-owned timber at a price above the OPA ceiling. 
much more cumbersome arguments. It must be shown that the level of state minima is unnecessarily high, that there is something wrong with the accounting techniques used by the state statute, and so forth.

The second and more important problem is political. The cause of minimum price laws can rally to its support a highly potent combination. It not only will be supported by those interested in the particular commodity, but also will find ready allies in the champions of "states' rights," the defenders of "small business" as well as all the irreconcilable opponents of price controls. This adds up to a virtually unbeatable combination. It is essential that political considerations be borne in mind in the ensuing discussion of OPS actions relating to state minimum price laws. Otherwise, a good deal of what was done by OPS might appear somewhat implausible.

In the summer of I95I, pressure was brought to bear on OPS to give recognition to a recently enacted Arkansas statute prohibiting "loss-leader" sales of cigarettes. On August 29, I95I, OPS issued Supplementary Regulation 53 to the GCPR (I6 FED. REg. 8798 (I95I)). This authorized Arkansas wholesalers and retailers of cigarettes to raise their ceiling prices to the levels prescribed by the Arkansas statute. The Arkansas law provided that cigarettes must be sold at or above "cost," which was defined as invoice cost plus 2 per cent for wholesalers and 6 per cent for retailers.

In the Statement of Considerations accompanying SR 53, OPS stated that it felt that recognition could be given to the policies of the Arkansas state legislature without impairing the price control program. OPS indicated that according to available data the number of sellers whose prices would be raised under SR/ 53 would be very small and that the magnitude of the necessary increases would be relatively minor. The Statement of Considerations pointed out that should other laws comparable to the Arkansas statute be called to the attention of OPS, "the Director will in like manner consider the relationship of such laws to the economic stabilization program and its effective execution and take such action as his findings may then indicate."

Having seen what one arm of OPS was doing in Arkansas, it is now appropriate to observe what another arm of the agency was doing in Minnesota. During the spring of I95I, the Minnesota State Legislature had passed a law ${ }^{73}$ by which the Liquor Control Commissioner was given certain regulatory powers over distilled liquors and wines, including the power to enforce minimum retail prices. Under that law the Commissioner had issued a minimum consumer retail price list effective July I, I95I. Some of these minimum prices were above the applicable GCPR ceiling prices. OPS thereupon filed a motion for an injunction in the federal district court in order to restrain the Commissioner from enforcing minimum prices higher than OPS ceilings. The injunction was granted on December $27,1951 .^{74}$

${ }^{73}$ Minn. Laws, x95 I, c. 400.

7t Judge Joyce, U. S. District Judge in Minnesota, issued a long memorandum order. On the 
The injunction did not quiet the Minnesota liquor dealers who, having learned of the OPS action in Arkansas, pointed out what looked like inconsistent treatment. For OPS, the situation was further complicated by the fact that SR 53 had also come to the attention of cigarette dealers in other states with minimum price laws. At the very end of his tenure as Director of Price Stabilization, Mr. DiSalle reached the conclusion that the Arkansas exception had been a mistake and on February I, I952 OPS issued a revocation of SR 53 (I7 FED. REg. I049 (I952)).

The Statement of Considerations accompanying the revocation pointed out that a re-examination of cigarette "loss-leader" statutes had shown "that they have broader economic implications than were anticipated when SR 53 was issued," and that OPS had been wrong in assuming that the Arkansas statute was a special case. Since the issuance of SR 53 , it had been ascertained that 26 other states had similar legislation. It would, therefore, be unfairly discriminatory to make special provision for Arkansas without allowing similar increases under the statutes of the other 26 states. "Taking into account this large number of sellers and the level of necessary price increases, the effect of an extension of SR 53 would be definitely inflationary. Under the circumstances, there is no alternative but to revoke SR 53." To permit an adequate publicity campaign in Arkansas, the effective date of the revocation was March I, 1952, one month after its issuance.

Shortly after the issuance of the revocation, Governor Arnall succeeded Mr. DiSalle as Director of Price Stabilization. Heavy pressure was brought to bear on him to reconsider the revocation. On February 29, I952, the effective date of revocation was postponed one month until April I, r952. The extension was issued to permit "complete examination of this matter." On April I, I952, OPS further postponed the revocation date until April 16. On April 16, 1952, the revocation was postponed indefinitely.

As the spring of $195^{2}$ rolled by, the June 30 termination of price control authority came inexorably closer. The problem of obtaining an extension of statutory authority became of greater significance. From the states with minimum price laws considerable pressure was exerted to have Congress amend the Defence Production Act in order to provide for complete recognition by OPS of state minimums. Needless to say, OPS was very much perturbed about the possibility of such Congressional action. With the hope of forestalling it, Revision $\mathrm{r}$ to SR 53 was issued on May 2I, I952 (I7 FED. REg. 4649 (I952)). It established a policy which OPS hoped to apply to all state minimum price laws which became effective after the GCPR. The Statement of Considerations pointed out that "A re-examination of the Arkansas situation

issue of the supremacy of federal laws, he stated, after an elaborate discussion of the authorities:

"The State Liquor Commissioner's authority is 'subject to the ceiling price' prescribed by OPS. Such a result is, of course, required by the United States Constitution. Indeed, if the authority of the State Liquor Commissioner were not subject to OPS ceilings, the net effect would be that a state could vitiate federal price control at will. If OPS' ceiling prices are deemed too low, there are available detailed and adequate procedures prescribed by federal law and OPS regulations to afford necessary relief. Recourse to OPS rather than to the state law is the proper method in such cases." 
has confirmed the conclusion that while a more general recognition of state minimum prices would be inflationary, SR 53 is neither inflationary nor unjustifiably discriminatory, when limited to a situation identical to that prevailing in Arkansas."75

In addition to enunciating this general policy, Revision $x$ reinstated the exception for Arkansas. One week later, the SR 53 treatment was extended to cigarette wholesalers and retailers in Alabama.

The tactical advantages which OPS hoped to obtain by reinstating SR 53 did not materialize. The drive for general recognition of state minimum price laws could not be thwarted. The so-called Bricker Amendment became Section 402(x) of the Defense Production Act, when the Act was extended on June 30, I952 (66 STAT. 300). It provided:

No rule, regulation, order or amendment thereto issued under this title shall fix a ceiling on the price paid or received on the sale or delivery of any material in any State below the minimum sales price of such material fixed by the State law (other than so-called "fair trade laws") now in effect, or by regulation issued pursuant to such law.

On July 17, 1952, OPS issued GOR 32 (I7 Fed. Stat. Reg. 6583 (I952)). It provided a method for the adjustment of ceiling prices as prescribed by the so-called Bricker Amendment. An appropriate state official had to certify that the state law was enforced and in effect on June 30, 1952. GOR 32 permitted the filing of applications for adjustment by individual sellers subject to state minimum price regulations as well as by state officials responsible for the enforcement or administration of such laws. Between October I, I952 and February 2, I953, twelve special orders were issued under GOR 32. Eleven of these applied to cigarettes. The states affected were Ohio, Maine, Minnesota, New Jersey, Wisconsin, New Hampshire, Tennessee, Kansas, Pennsylvania, Montana, and Connecticut. One applied to grocery products. In effect, it gave recognition to a Montana law which provided that chain stores sell at a higher markup than other retail grocers.

It is almost impossible to assess accurately the consequences of the Bricker Amendment. Price controls were terminated too quickly after it became effective. Moreover, by the fall of 1952 inflationary pressures, in most areas of the economy, were disappearing. For example, ceiling prices on liquor-a commodity on which the

${ }^{75}$ Three reasons were given. First, that the number and the magnitude of the increases required in Arkansas were small; second, that the Arkansas statute was under active consideration and in the final stages of enactment at the time of the issuance of the GCPR; third, the Arkansas statute related only to cigarettes, a commodity having "unique characteristics which have made them the subject of special attention by state legislatures." Under this "unique characteristic" doctrine, OPS felt that alcoholic beverages should also be included. While these were not unique for the same reason that cigarettes were, the right of state legislatures to pass laws "in the interest of public health and morals" ought to be recognized when dealing with alcoholic beverages. Having carved this exception, the Statement of Considerations pointed out that "on the other hand, it would obviously be inflationary to extend SR 53 to other State minimum prices embracing commodities other than cigarettes and liquor, to statutes which reached active and final consideration only after the issuance of GCPR, to States in which the minimum prescribed retail price is higher than the ceiling prices of a substantial number of sellers, so that the recognition of the minimum prices would substantially increase general selling prices, or to permit a markup on the increased cigarette tax effective November I, 195I which would substantially increase retail prices of cigarettes." 
Bricker Amendment could have had profound effects-had already been suspended. The Bricker Amendment contained safeguards against some of the worst abuses. In this regard the provision excepting state-fair-trade laws is of great importance. This excluded the resale price maintenance laws which are on the books in at least fortyfive states. Furthermore, the requirement that minimum price laws must be "now in effect" kept out a lot of dormant legislation. It presumably excluded most of the general "unfair competition" laws.

In conclusion, it is safe to say the Bricker Amendment was not as bad as it could have been. In fact, under the peculiar economic conditions which prevailed, it could not have done much harm. However, during a protracted period of real inflation, the consequences would surely have been different. For the reasons already indicated, recognition of state minimum price laws would result in a weakening of the controls structure which could not be tolerated during a period of all-out inflation. At such a time, a price control agency must insist on the supremacy of federal law. OPS experience provides a graphic illustration of the dangers of the slippery slope-the first compromise with the principle of federal supremacy in Arkansas, leading by an almost inevitable succession of events to the Bricker Amendment. Whether OPS could have successfully adhered to the principle of federal supremacy in the peculiar economic climate of $195 \mathrm{I}$ and 1952 is perhaps questionable. However, during a period of real inflation, it is imperative that there be no compromise.

\section{ConcLusion}

Price controls are imposed only when the free market system no longer functions effectively as an economic regulator and when its continued operation, without artificial restraints, would lead to economic chaos. The basic concern of both price controls and the antitrust laws is the same-to keep our economy healthy. Price controls are a drastic remedy designed for an acute situation of short-run duration. The antitrust laws, on the other hand, operate on a long-term basis.

During periods of sharp inflationary pressure the necessity of countering the acute condition-inflation-means that certain antitrust objectives must temporarily be subordinated. Only the blindest of antitrust dogmatists would quarrel with this. For the very fact that price controls deal with an emergency situation provides assurance that there will be little or no real after effect when inflation has subsided. A simple example illustrates this point. One of the standard techniques for establishing the ceiling prices of a new seller is to require him to "borrow" the ceilings of his closest competitor. This sort of thing sends chills down the spines of some "antitrusters," including Mr. and Mrs. Hale. ${ }^{76}$ However, on any realistic level, this "borrowing" cannot be interpreted as government endorsement of price leadership. It is simply a convenient technique-at times, the only technique-for giving a seller who had never sold in an uninflated market an uninflationary ceiling price. There is no reason to believe that it should produce any undesirable after effects, for

${ }^{70}$ Hale and Hale, supra note $\mathrm{r}$, at $6 \mathrm{rg}$. 
when controls are lifted the old ceiling prices will rarely have more than academic interest.

That we do have, under a system of price controls, a subordination of certain antitrust objectives should not be cause for alarm. For, to subordinate does not mean to ignore. It is imperative that a price control agency have a real awareness of antitrust considerations. Liaison with the Justice Department and the Federal Trade Commission is obviously of value, if only to remind the harried price controllers that there are antitrust considerations which ought to be kept in mind. Beyond this, it is fundamentally the responsibility of the lawyers attached to the operating divisions of the price control agency to be alert to antitrust problems. While liaison between the price control agency and the Antitrust Division can deal with the larger problems of first impression, the great bulk of potentially controversial situations-such as those arising in the conduct of industry advisory committee meetings-will occur in the operating divisions and probably never get beyond that stage.

Active liaison will also permit the Antitrust Division to do a proper policing job after the termination of controls. This will insure that antitrust considerations which might have been subordinated during the emergency will receive their proper due when the emergency ends.

Finally, OPS experience clearly indicates that there rarely is such a thing as "allout inflation." While selling prices were flush against ceilings in many parts of the economy, there were always some areas-and, toward the end of the price control program, very substantial ones-in which competitive factors, rather than ceilings, determined prices. Thus, even during a period when controls are in effect, there is need for antitrust enforcement.

Although state minimum price laws, like the antitrust laws, are addressed to economic conditions differing greatly from those in a period of real inflation, their collision with price controls is direct and head on. Consequently, they must yield to price controls if serious damage to the stabilization program is to be averted when inflationary pressures are rampant. 